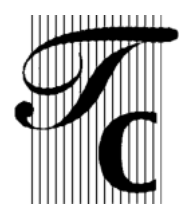

\title{
Negative visibility and 'the defences of the weak': The interplay of a managerial culture and prisoner resistance
}

Theoretical Criminology 2020, Vol. 24(2) 202-22I

(C) The Author(s) 2018

Article reuse guidelines: sagepub.com/journals-permissions DOI: 10.1 I $77 / \mid$ 3624806/8779404 journals.sagepub.com/home/tcr @SAGE

\section{Anton Symkovych}

University of Johannesburg, South Africa; Centre for Advanced Study-Sofia, Bulgaria

\begin{abstract}
While being structurally subordinate, prisoners are neither powerless nor mute. Drawing on semi-ethnographic research in a Ukrainian medium-security prison for men, in this article, I advance the concept of 'negative visibility' - that is, an administration's fear of external attention and intervention, and make a case for the interplay of prisoner resistance with a managerial culture. Using Soviet penal and managerial legacies as an example, I argue that structure can be both constraining and enabling even within the milieu of the gross power imbalance of which prison is an archetype, thereby attesting to the coherence of agency and structure and the contingency of power. Furthermore, by highlighting that prisoners may undermine officer power for all sorts of reasons, including opportunistic and selfish ones, this study cautions against romanticizing the 'defences of the weak' and a priori politicization of prisoner resistance.
\end{abstract}

\section{Keywords}

Agency, power, prison, prisoners, resistance, structure, Ukraine

\section{Introduction}

Prisons are debilitating (Kauffman, 1988), brutal and coercive places (Scraton et al., 1991). Within them, people's rights and dignities may be suspended (Liebling, 2004).

\section{Corresponding author:}

Anton Symkovych, Sociology Department, University of Johannesburg, PO Box 524, Auckland Park, Johannesburg, Gauteng 2006, South Africa.

Email: asymkovych@uj.ac.za 
Men, women and children may endure physical, sexual and emotional abuse (Othmani, 2008), pain (Christie, 1978), fear (Pallot and Piacentini, 2012), 'illegitimate patriarchalism' (Mathiesen, 1965), stagnation (Ugelvik, 2014), numerous deprivations (Sykes, 1958) and deterioration, depersonalization and suffering (Cohen and Taylor, 1972).

Nonetheless, in his seminal work, The Defences of the Weak, Mathiesen (1965) convincingly argues that despite an inherent and radical power inequality, prisoners are not powerless mutes. They manage to 'defend' themselves. Although Foucault's (1978: 95) claim that 'where there is power, there is resistance' may sound trite, compelling evidence from around the world demonstrates that prisoners, to various degrees of intent and efficacy, contest and circumvent officers' 'cracked' power (Sykes, 1958: 53; inter alia, Akoensi, 2014; Bosworth and Carrabine, 2001; Cloward, 1960; Crewe, 2009; Karklins, 1989; Khlevniuk, 2004; McDermott and King, 1988; Pallot and Piacentini, 2012; Thomas, 1984; Ugelvik, 2014).

At the same time, however, and notwithstanding the plethora of global data, we know little about the interplay of localized political culture and prisoner resistance. In particular, there is scarce information about how prisoner resistance operates within Central European institutions following the collapse of the authoritarian Leninist regimes. In this article, I work to fill this gap by advancing the concept of 'negative visibility' (Thomas, 1984: 226), by which I mean the prison administrators' fear of external attention and intervention, in order to highlight the coherence of a political climate and prisoner resistance.

Drawing on a semi-ethnographic case study in a Ukrainian medium-security prison for men, I discuss how these prisoners engaged the Soviet legacy of a scapegoating culture to circumvent and fend off prison officer power (henceforth officer power). While mindful of the inherent limitations of a case study design, I argue that notwithstanding the structural determinants of the gross power disparity, amplified by Ukraine's totalitarian past and current struggles to give human rights real meaning, the interactional nature of power means that neither officers nor prisoners are completely or permanently powerful or powerless. In their interactions, men assess, utilize and reconstitute structures that can equally constrain and promote their actions.

\section{Prisons as power places}

Not all prisoners are created equal, but all react as agents to penal power in general and to prison officers in particular. The concept of agency captures the complex ways in which people are reflexive of their human condition and always could have acted otherwise in a given situation (Giddens, 1984). Power, in prison as elsewhere, operates at two levels. First, power-as-domination constitutes an organizing force of social orderthrough enduring stabilizing, routinizing mechanisms such as ideology, tradition, culture, law and its enforcement apparatus, the economy and socialization (Garland, 1990; Giddens, 1984; Scott, 2001; Smith, 2008; Weber, 1962). Second, power represents a relationship among people in situ whereby one side can exercise its will against the will of the others (Weber, 1962; see Gangas, 2016 on capabilities versus capacities).

Structure and agency cohere and connect: the former, as an external factor, shapes the behaviour and resources (including available meanings) of agents, while agents give 
meaning to, reproduce, challenge, shape and alter structures (Giddens, 1984; Rubin, 2017; Smith, 2008). This dialectic requires two disclaimers. First, social commentators tend to equate agency with resistance. In her critique of this tendency, Rubin (2017) accurately observes that by implying or expecting that agency must repel structure, these scholars, perhaps unintentionally, deny agency to those who accept existing structures (see also Crewe, 2009). Second, following from the first, structure may constrain and enable alike (Gangas, 2016; Giddens, 1984; Rubin, 2017). In prison, although generally constraining, structure nonetheless can assist prisoners in augmenting agency and selfworth, serving as a source for the reimagination and reinvention of people's identity (e.g. Bosworth and Slade, 2014; Ghorashi et al., 2018; Symkovych, 2017a; Ugelvik, 2014). Furthermore, while prison administrators wield significant power, they themselves face a threat of chastisement and even removal if higher authorities deem them not to be in control. Thus, prison authorities often feel apprehensive of external attention or intervention, and prisoners exploit this fear of negative visibility in their contestation and circumvention of officer power (Calavita and Jenness, 2014; Martin, 2014; Symkovych, 2018; Thomas, 1984).

Prisoners exercise agency and use structure differently and for myriad reasons and purposes: actively and passively, dissentingly and obediently, consciously and otherwise, intentionally and unintentionally, collectively and individually, meaningfully and not, quietly and disruptively. Conversely, officers and prison administrations in general may be cognizant, oblivious or indifferent to prisoner (re)actions, and, consequently, adjust or not their power in response (Bosworth and Carrabine, 2001; Hollander and Einwohner, 2004; Mathiesen, 1965; Rubin, 2015, 2017; Scott, 2001; Wrong, 2004). Prisoners react not only to penal power and imprisonment in general but also to concrete institutions. Such reactions, including lasting adjustments, coping, resistance and adaptations, predicate on an array of factors - personal (e.g. biographical, psychological, identity), as well as institutional (e.g. regime, architecture, officers and other prisoners) (Cohen and Taylor, 1972; Crewe, 2009; King and Elliott, 1977). In essence, prisoner reactions stem from the need to assert their subjective identity, to maintain autonomy and a measure of control (agency), to improve their lives or, sometimes, merely to survive in a brutal and totalizing environment (Bosworth, 1996; Bosworth and Carrabine, 2001; Cohen and Taylor, 1972; Crewe, 2009; Ghorashi et al., 2018; Goffman, 1961; Karklins, 1989; Martin, 2014; Mathiesen, 1965; Pallot and Piacentini, 2012; Reed, 2003; Ugelvik, 2014).

Equally, prisoner reaction to penal power in the form of 'frictions' may often be normal, sometimes almost reflexive and automatic human behaviour devoid of political intentions or special psychological significance (Rubin, 2015; see Carrabine, 2005: 908 on 'libidinal attractions of transgressing'). ${ }^{1}$ In sum, prisoner reactions to prison and prison officers form a rich diversity, 'with different meanings, causes, and effects' (Rubin, 2015: 25), at times 'superficially similar yet substantially different' (Hollander and Einwohner, 2004: 543). Inevitably, we must be selective in what we study and report. In this article, I limit the analysis to tactics of contesting the officer power that prisoners and officers alike considered consequential: that is, intentional, overt resistance recognized by prisoners, officers and me as an observer (Hollander and Einwohner, 2004). By using the concept of negative visibility, I illuminate the interplay of a managerial culture with prisoner resistance. 


\section{Soviet legacies and post-Soviet realities}

Ukraine's penal regimes draw together totalitarian legacies and the state's liberalizing efforts. The country has undertaken extensive reforms, granting prisoners major rights and allowing local and international inspectors, as well as volunteers, into its prisons. Along with losing control of 20,000 prisoners in 29 prisons following the Russian occupation of Crimea and the East in 2014, Ukraine has recently reduced by two-thirds its prison population to fewer than 60,000. However, because of cultural attachment (Garland, 1990; Smith, 2008) and the country's dire financial straits, many Soviet legacies persist (see Pallot, 2015). A militaristic and overcentralized organization of the prison system, a managerial culture of evasion of responsibility and displacement of blame, barrack-style collectivist housing of prisoners, framing prisoner labour as a marker of rehabilitation and compliance, and an overreliance on prisoner-trustees in prison management represent the major relics of Soviet penality (see Symkovych, 2017b, 2018). The Gulag still serves as a reference point for (a fortiori 'western') commentators, reformers and even people working and living in the Ukrainian prison system (see Oleinik, 2003; Pallot and Piacentini, 2012; Piacentini and Slade, 2015).

Prison inspections depict health care in Ukrainian prisons as abysmal and prison infrastructure as often broken beyond repair. They report localized overcrowding exacerbated by severe understaffing, albeit mostly in remand prisons. Despite continuous liberalization, some prison policies and practices remain anachronistically over-restrictive (CAT, 2017; CPT, 2017). That 12.6 per cent of all European Court of Human Rights (ECtHR, 2018a) cases in 2017 came from Ukraine attests to both the growing rights consciousness among Ukrainians and the lack of the rule of law in Ukraine. ${ }^{2}$ One of many disjunctions between rights-in-law and rights-in-practice lies in Ukraine's frequent failure to properly investigate and prosecute human rights violations in its prisons, including suspicious deaths in custody (CPT, 2017). As a 'near democracy' (Karstedt, 2013) still emerging from Soviet totalitarianism, Ukraine constitutes an anomic environment whereby many people who have already embraced the rights that endow their citizenship must deal with a state whose laws, institutions and street-level bureaucrats do not always acknowledge the new normative expectations of ordinary citizens, including prisoners. The 2013-2014 mass protests, known as the Maidan or Revolution of Dignity, epitomized this disjunction and the unwillingness of many to accept it. These events marked further departure from the Gulag legacy of legal nihilism, passivity and resignation in the face of state violence, as well as Ukraine's increasing distinctiveness among other post-Soviet societies (see Erpylyeva, 2018; Khlevniuk, 2015).

\section{The research site and methods}

This discussion draws on five months of participant observation and informal conversations in a medium-security prison ('strict regime' in the former Soviet and modern Russian taxonomy) for sentenced men in the Kyiv region of Ukraine. Following two years of arduous access negotiations, the Ukrainian Penitentiary Service (UkrPS) allowed a study in this 'model' prison that served as a testing ground for new practices. The UkrPS exposed officers from other Ukrainian prisons to these practices as a means of 
dissemination during their initial and refresher courses at the nearby Training Academy. The typical topography of a medium-security prison ('correctional colony') meant that the prison's secure compound encompassed a vast industrial zone with various workshops and an attached residential zone. This was further subdivided into local zones, each housing several squads of about 50 prisoners each (see Pallot and Piacentini, 2012 on otryad).

The prison population of 800 comprised predominantly recidivists, mostly from Kyiv and the surrounding region (cf. Pallot and Piacentini, 2012 on coercive mobilization in Russia). Severely understaffed, on a normal day the prison had around 20-30 uniformed officers inside the secure compound. Officers belonged to one of four departments with specific duties and roles. Armed guards monitored the external perimeter and incoming parcels but did not enter the secure compound. Patrols, equipped with batons, handcuffs, radios and mace sprays, policed the secure compound. Security officers gathered intelligence, while squad supervisors acted as case managers.

My fieldwork entailed daily visits, including weekends and holidays. Initially within sight of an officer and increasingly on my own, I mingled relatively freely in the workshops, dormitories, local zones (exercise yards) and the trans-zone checkpoint, chatting with people and observing daily life (cf. Pallot and Piacentini, 2012 on omnipresent minders and other challenges of independent research in Russian prisons). A native Ukrainian, I conversed in Ukrainian or Russian, depending on the interlocutor. As I discuss elsewhere, my authenticity, ad hoc resolution of moral dilemmas and my independence from the authorities ${ }^{3}$ (who subjected me to a prolonged and humiliating quest for research authorization, occasionally suspending my access afterwards) won me a measure of sympathy and trust from prisoners and officers alike (Symkovych, 2017a, 2017b). Because many prisoners and officers appointed themselves as my informal guides into the complex prison world, I quickly mastered the prison's practical norms, its jargon and power dynamics. Eventually, I managed to speak to about a third of the prisoners and almost all officers.

Additionally, I attended daily staff briefings and various other meetings, such as a regular prisoner grievance forum with an overseeing prosecutor. I also selected 20 prisoners and 21 members of staff (including the prison commander) for semi-structured interviews to explore in depth the salient themes that emerged during informal conversations and observations. The interviewees represented the identified diversity of views, prison experiences and positions that existed in formal and informal hierarchies. As I lived with officers in the Training Academy, we discussed my emerging findings daily together with their experiences in prisons across Ukraine.

Data analysis entailed a review of field notes and recordings of conversations and semi-structured interviews to assess the themes and patterns first identified in the extant literature and those that emerged from observations and conversations (see Bottoms, 2007; Pallot and Piacentini, 2012). The thematic analysis involved assessment of the themes' frequency and their intensity - that is, their deduced relevance to research participants gauged through the participants' choice of words, tones and other signifiers (Berg, 2001; see Cohen and Taylor, 1972 on collaborative research and Berger, 2001 on ethnography as a joint production). 


\section{The dynamics of 'negative visibility' and 'the defences of the weak': Structurated and structurating prisoner contestations}

The prisoners in my study reacted to officer power in manifold ways, sometimes accepting, but often undermining it through trivial frictions or concerted resistance to which they attached important, political meanings. Focusing here on the latter case, I use the following taxonomy of prisoner power vis-a-vis officers: official grievances, force, and coercion (Bachman et al., 1968; Hepburn, 1985; Kauffman, 1988; Scott, 2001; Wrong, 2004). Obviously this taxonomy is neither ideal nor exhaustive, ${ }^{4}$ not least because the power nomenclature tends to centre on those in dominant rather than subordinate positions. However, it captures the most significant and consequential, for officers and prisoners alike, strategies and tactics of prisoner 'defence' against structurally more powerful officers. While typical across jurisdictions, I argue that these forms of prisoner resistance can be coloured by a local political climate. The concept of negative visibility allows us to explain how structurally disempowered agents manage to reconstitute structure for their own benefit by exploiting the Soviet legacy of scapegoating - that is, the administrators' evasion of responsibility and hierarchical displacement of blame. Thus, despite the totalitarian past and the embryonic rule of law, the prisoners were capable of contesting officer power by engaging the administrators' fear of negative visibility, thereby attesting to the coherence of agency and structure and the contingency of power.

\section{Official grievances}

Prisons struggle to reconcile control priorities with the recognition of prisoners as rightbearing subjects (Calavita and Jenness, 2014). As part of its 'de-Communization' and 'Europeanization' projects, Ukraine has been expanding the rights of its citizens, including its prisoners. The Constitution of Ukraine (1996) guarantees everyone the right to appeal, including to the Parliamentary Human Rights Ombudsperson, any decisions and (in)actions of state bodies and their personnel. It allows citizens to defend their rights 'in any other manner which is not explicitly prohibited by the law' (Article 55). As in other jurisdictions, while few officers or prisoners in my study denied that prisoners are humans with some rights, the exercise of these rights often attracted disapproval and censure (see Calavita and Jenness, 2014).

This uneasiness and the administration's palpable efforts to avoid prisoners appealing to outside bodies suggest that, first, official grievances could undermine officer power, and second, that the administrators preferred to avoid negative visibility. The prisoners taking this contestation route usually explained their motives through the discourses of rights, justice and fairness (normative expectations). One prisoner, about 40 years old, who had served several custodial sentences in the past, highlighted not only his resolution to assert his rights and human worth by filing official grievances but also the shifting power balance within prison, that appeared to reflect broader changes in this country of 'near democracy': 
I don't submit grievances because I have nothing else to engage myself with. And I am well aware that the administration doesn't like it, [that] it will start pressurizing me - not necessarily overtly. But they need to be constantly reminded that we are not animals, have rights, and that they are not czars and gods [or] above the law [...] They respond by pressurizing because they know that they have violated the rules, prisoner rights, and that they can be punished [for this] by those above them. They may like to think they are gods, but they are not, not even czars. The Gulag times are gone.

The prisoners I spoke to insisted on the limits of officer power (what Tamanaha, 2004 considers a constituent of the rule of law) and deemed it their duty to resist any encroachment or abuse of power by administrators. Although they rarely disapproved of those engaged in 'naming, blaming, and claiming' (Calavita and Jenness, 2014: 49), despite its potential threat to the status quo of peace (Symkovych, 2018), prisoners regarded these bureaucratic quests more as legitimate leisure with a tint of eccentricity than as a form of resistance. The inertial totalitarian legacy of the collusion between state branches, blended with the undeserving prisoner status (Khlevniuk, 2004; Piacentini and Katz, 2017), partially explains this scepticism. One man from central Ukraine told me about police physical abuse he experienced during his arrest there and cautioned about the signal divergence of the law-on-the-books and law-in-action:

Don't be fooled that there is a [overseeing] prosecutor here weekly - it all depends a lot on the prosecutor and his $[s i c]$ relationship with the prison commander. Perhaps it's not that bad here, because Kyiv is near, and because we are in [the UkrPS's showpiece]. But if you go a bit farther from Kyiv, it's all a mere show. [For example] in Cherkasy a city prosecutor, a prison commander and the head of the city police [used to] go hunting together. Do you think the [city] prosecutor would allow a prosecutor for prisons to cause problems to the prison commander? [smiles sarcastically]. Over some random con?! It goes like that: you scratch my back-I'll scratch yours.

(Prisoner)

The prisoners were likely right to be sceptical: following one of the weekly grievance fora the prosecutor summoned the officers and advised them how to write disciplinary reports so that they would withstand a legal challenge (see Garland, 1990: 255 on a 'signifying practice'). Despite this often well-founded (see CAT, 2017: para. 37) cynicism, formal channels acted as 'the input from the periphery' (Pallot, 2015: 690) even during the Gulag, enabling Soviet prisoners to temper officer power through written grievances (Karklins, 1989; Khlevniuk, 2004). As in Calavita and Jenness's (2014) study, Ukrainian administrators tried to confine everything to the local level, avoiding negative visibility, that is, external attention from the area manager's office, monitoring bodies or the media (I discuss this in more detail in a subsequent section). I witnessed one deputy commander raging after learning of a prisoner's new complaint to the Parliamentary Human Rights Ombudsperson. The official was powerless to stop it because of the existing oversight that constrained his power. This reaction suggests that, despite the general pessimism, prisoners could employ structural provisions to check officer power. 
Feeling apprehensive about negative visibility, not least because many 'pragmatic repetitive routines of daily practices' (Garland, 1990: 255) in the prison violated the law (see Symkovych, 2018) and, if exposed in an official grievance, could cause problems, the administration applied the rule by law to 'serial litigators'. Whereas the administration overlooked and relaxed many regime restrictions from practical necessity, not least because of understaffing, and for the comfort of officers and prisoners alike (Thomas, 1984), officers tended to be less discretionary with 'frequent filers' (Calavita and Jenness, 2014: 27). The officers often cynically emphasized that they enforced a certain rule only because these prisoners 'want[ed] everything to be according to the book' (see King and Elliott, 1977). The unintended consequence of such repression was that these prisoners often felt emboldened and empowered because they interpreted coercion-in-response as the effectiveness of their pressure (Calavita and Jenness, 2014; see Sparks et al., 1996: 288 on a 'mad litigious prisoner'). Furthermore, most front-line officers lacked training in completing reports and proved generally ignorant of legal issues, thus feeling vulnerable if officially challenged. The prisoners employed this structural weakness to fend off and dilute officer power.

\section{Force}

Prisoner use of force rests on a spectrum of factors (Bottoms, 1999; Sparks et al., 1996). Although an archetype of resistance, force often has only short-term effects over a limited number of people (e.g. Foucault, 1975/1991; Hepburn, 1985; Karklins, 1989; Kauffman, 1988). Nevertheless, prisoners' physical assaults on staff, as in other jurisdictions, constituted a real threat and had a direct bearing on officers' exercise of their power (see Kauffman, 1988; King and Elliott, 1977; Sparks et al., 1996).

Perilous understaffing, combined with the prison topography and en masse prisoner movement, sometimes enabled prisoners to assault officers with relative impunity:

There was once a young práporschyk [patrol officer] unlocking the local zone gates when some sort of altercation erupted. Stupid of him-instead of backing down and perhaps returning with his partner, he was arguing with [a group of] prisoners. Somebody hit him from the back, then others added [punches]. When there was an inquiry, obviously nobody has seen nothing [the interviewee being sarcastic].

(Prisoner)

This quotation illustrates that while prison life is replete with conflicts, amassed annoyance and frustration that can all easily escalate into violence (Sparks et al., 1996), prisoner power is not always 'a defence of the weak': it may be opportunistic, accidental resistance, if not predatory and selfish behaviour. As situated agents, prisoners often calculate cost-effectiveness, and their generally, but not necessarily, rational actions may be devoid of political intentions or moral justifiability. Conversely, structural factors, while enabling the prisoners to use force against staff, often diminished its rationality, as one 'ordinary' prisoner argued: 
Well, I can hit a práporschyk [patrol officer]. I can kill him for that matter. What for? To spend the rest of my life in krýta [maximum-security prison]? What will this do for me? Nothing good. As it is, I will probably leave behind two years [i.e. will be released earlier]. They [officers] are not beasts - well, some of them want to show that you are nobody, but it's because they are nobody. But there are other ways to show them this - hitting in the face is not smart, you won't achieve anything — perhaps a second of joy, but then you'd be regretting.

Prison conditions have improved significantly compared to the repressive Soviet era and the 1990s when prisons struggled to provide food or basic amenities, prisoner abuse was commonplace, and staff went without pay for months (see Piacentini, 2004). This living memory contrasted with improved conditions and staff-prisoner relations, rendering force less justifiable (see Cohen and Taylor, 1972 on collective memory; also Crewe, 2009; King and McDermott, 1995; Scraton et al., 1991). Furthermore, Ukraine's 'Europeanization' has led to shorter sentences with early release on parole more common. Empirical evidence suggests that prisoners are more likely to transgress when they are still far from being released (Bottoms, 1999; see Garabedian, 1963: 140 on 'anticipatory socialization'). In addition, assaulting an officer could lead to an additional sentence. Whereas the threat of additional time fails as a deterrent when prisoners are already serving long sentences, especially when parole prospects are bleak (Kauffman, 1988; King and McDermott, 1995), the availability of parole meant many prisoners regarded force as too costly a means of resistance (see Crewe, 2009).

Although prisoners aspired to parole, the use of force against staff was not unknown. While no incidents occurred during my fieldwork, my research participants shared stories about previous prisoner-staff physical confrontations in this and other prisons. The UkrPS and the Ukrainian media occasionally report serious physical assaults on prison staff: from spilling boiling water onto an officer's face to a stabbing, and even murder (Radio Freedom, 21 August 2017; UkrPS, 28 February 2008, 27 April 2009, 10 June 2016). ${ }^{5}$ Notwithstanding the standard caution about official figures, the UkrPS reported a total of six cases of prisoner attacks on staff in 2017, including two in the research prison. Despite the fact that during the five months of my fieldwork there were no officer assaults, officers were wary of these what Ugelvik (2014: 159) terms 'untrustworthy bodies'. Conscious of their vulnerability to opportunistic assault, officers did not usually indulge in 'heroics' by restraining prisoners when alone (Kauffman, 1988). They had to use discretion when deploying their power, assessing the probability of prisoner physical resistance. Hence, while en masse housing, combined with serious understaffing, enabled prisoners to use force, the improved prison conditions, liberalized penal regime and the potential for the state's repressive backup (see Pallot and Piacentini, 2012) diminished the appeal of this form of resistance. Within these structural realities, neither side could remain completely powerful nor permanently powerless and 'defenceless'. Simultaneously, the penal regime directly mediated the form and frequency of prisoner resistance.

\section{Coercion}

Despite the law explicitly prohibiting prisoners' defiance, especially strikes (CriminalExecutive Code of Ukraine, 2003: Articles 9, 107.4 and 118.4), prisoner non-compliance 
constituted a powerful coercive tool. ${ }^{6}$ As in all social prisons (versus 'electronic coffins', King and Elliott, 1977: 3), the officers relied implicitly on prisoners' co-operation to maintain the prison routine (Mathiesen, 1965; Sparks et al., 1996; Sykes, 1958). In this severely understaffed prison, an ever-present possibility of prisoners' withdrawal of cooperation posed a real threat that loomed large in the prison commander's and officers' minds. While the prison possessed a 'penal back-up' (Pallot and Piacentini, 2012: 97) to overcome any individual or collective non-compliance, its occurrence would disrupt 'smooth administration' (Mathiesen, 1965: 54) and create the negative visibility that the managers realistically feared as I explain next.

Collective coercion. While existent, overt group non-compliance in Ukrainian prisons appears to be sporadic. The UkrPS reported one case of generic group disobedience, four cases of group food refusal, 10 cases of group self-harm and six cases of 'other highprofile emergences' in 2017. Although unclear what exactly constituted 'disobedience', one UkrPS press release mentioned 100 prisoners refusing to carry out work (UkrPS, 15 August 2016). Although I did not observe open collective protests during my fieldwork, several months before my arrival a group of about 50 prisoners staged a hunger strike at this prison. This was to coerce the administration to transfer a newly arrived prisoner belonging to the prisoners' hierarchical top level (see Symkovych, 2017c) to a prison of his choice. That crisis prompted a visit from the area manager's office, individual 'prophylactic' talks with each of the prisoners on strike, an agreement to transfer the prisoner in question and eventually a new prison commander.

Despite the apparent effectiveness of coercion through instigating negative visibility, several factors rendered collective non-violent resistance less popular among these prisoners. First, recent penal developments meant that Ukrainian prisoners had much more to gain than to lose from co-operation with officers, most notably the tacit institutionalized circumvention of many restrictive rules and the increased possibility of early release. Second, prison conditions and officer-prisoner relationships overall had significantly improved enough not to warrant frequent mass prisoner resistance (see Carrabine, 2005; Useem and Piehl, 2006; cf. King and Elliott, 1977). Third, the post-Soviet socio-legal reforms, together with demographic changes inside prisons, had been eroding group solidarity and the willingness to forfeit personal welfare for the collective good (Bosworth, 1996; Carrabine, 2005; Crewe, 2009; Mathiesen, 1965; Symkovych, 2017b). While still holding power, the smotryáshchi, that is the confrontational leaders at the symbolic head of the informal prisoner hierarchy, had been losing their charismatic and traditional authority (Symkovych, 2017c; see Weber, 1962). That authority is central to organizing and sustaining collective protests, as one experienced prisoner explained:

If there is to be group disobedience, there should be an organizer. A person, or several, who will be a negotiator. He should be ready for the consequences-segregation cell, rozkrutka [additional sentence]. And these days they've got no guts (públika slabényka). Those 50 or something that [went on hunger strike], as soon as the commission [from the area manager's office] came, put their tails between the legs and all went for supper. Those who didn't, were shipped out [to 'harsher' prisons]. 
A paradox emerges. On one hand, the administration held enough power to punish those prisoners who caused negative publicity. On the other hand, each instance of group disobedience de facto constituted a crisis, whereby the local managers faced serious repercussions. Almost without exception, the UkrPS released statements holding local administrators responsible for 'substandard security and lack of professionalism' immediately following reports of prisoner self-harm, suicide, escapes, fights and any other manifestations of the breakdown in order and control. The press releases, normally nebulous, often contained passages like the following, attesting to the magnitude of the Soviet scapegoating culture:

On [date] in the UkrPS Headquarters the UkrPS First Deputy held a meeting with the managers of [names] regions and commanders of [names of prisons] concerning serious shortcomings in security and professional work in the aforementioned establishments, and the emergency which took place in [name of another prison] on [date]. The degree of guilt [sic] of the officials has been established; the actions to improve the state of affairs, to secure order, to prevent and debar negative tendencies and conflict situations amidst prisoners have been outlined.

(UkrPS, 5 June 2008; also UkrPS, 25 January 2010, 9 March 2010)

Even though the UkrPS officially denied problems in a particular establishment and framed each instance of prisoner non-compliance as prisoner attempts at coercion, my analysis of UkrPS press releases over four years suggests that, typically, prison commanders were chastised for lapses in control (e.g. UkrPS, 5 July 2010, 14 July 2010). Following the Soviet legacy of official denial most reported official inquiries did 'not find facts substantiating prisoners' grievances' that triggered non-compliance. Nevertheless, prison and area administrators were still 'called to account' - thus demonstrating that prisoner coercion through engaging the administration's fear of negative visibility could be effective (e.g. UkrPS, 8 August 2007, 26 August 2009; also CPT, 2015a, 2015b).

Individual coercion. Although structurally 'weaker' than the state's penal might, prisoners managed to successfully counteract staff power, collectively and individually. However, the resources for individual resistance, apart from official grievances and physical force, were scarce. Within these structural constraints some prisoners used their bodies as an ultimate resource to resist officer power (see also McDermott and King, 1988 and Sparks et al., 1996 on 'dirty protests'). One prominent coercive tactic was self-harm (cf. Crewe, 2009 on 'muppets' and 'weakness').

Self-harm and suicide in custody are complex phenomena (Liebling, 1992) and may serve as a final assertion of agency in a struggle where 'further compromise, further retreat becomes a total and complete surrender' (McDermott and King, 1988: 373). Indeed, the UkrPS framed prisoner self-harm as manipulative behaviour: the official press releases unwaveringly explained disclosed self-harm incidents as prisoners' attempts 'to avoid justified punishment' and coerce staff (e.g. UkrPS, 14 May 2010, 18 August 2010). The Prison Bye-laws (2014) explicitly prohibit self-harm and, to emphasize the framing of self-harm as prisoners' manipulation and coercion, stipulate that if taken to the medical ward from a punishment cell or a segregation unit following self-harm, prisoners had to 
return to segregation to complete the prescribed term (Rule xxvii: 5; cf. Kauffman, 1988). Having no relevant training, officers appeared oblivious to the possibility of alternative reasons for prisoner self-harm. ${ }^{7}$ Few officers perceived self-harm as a genuine attempt to get help or 'escape' (Dear et al., 2000: 165), but rather considered it to be manipulative attention-seeking, evasion of punishment, or pursuit of other selfish ends - that is, a purely instrumental form of prisoner power:

It is one of the methods used to influence the administration.

(Psychologist)

They open up (vskryváyutysya) [cut open veins] to get attention. They know this will cause fuss, TV will report [it], human rights activists will be screaming that prisoners have again opened up to protest against the 'inhuman conditions' and atrocious staff-they're like kidsas a rule, they open up when they know they'll [have to] go to the seg block. Look, they're not going to die. If they really wanted, they would. They'd cut veins in the armpit so you can't stop blood. But they just scratch. They want attention —and perhaps a 'holiday' in the medical ward.

(Patrol officer)

As with other forms of prisoner power, some men occasionally self-harmed 'effectively' to circumvent official rules. Prior to my fieldwork, the prison commander reassigned a squad supervisor when five prisoners cut their wrists to protest at this officer's coercive, albeit legal, demands. I observed other situations when prisoners threatened to cut their veins. This 'strategy of despair' (Pallot and Piacentini, 2012: 115) was effective at both the individual and group level despite official trivialization and the authorities' assertion that they would not submit to prisoner manipulation. Like other modes of resistance, it exploited the administration's fear of negative visibility and the Soviet legacy of hierarchical blame-assignment coupled with displacement of responsibility:

It is our Soviet way. There always should be an appointed scapegoat. So if a prisoner commits suicide, the heads of a psychologist, zampolit [Deputy], perhaps even a prison commander's and deputy area manager's would roll. There is always reason to justify: 'shortcoming in work', 'poor preventive work', 'official negligence', whatever. It's out of your control, but you would surely lose your bonus for that month at best, or you can be reprimanded, have promotion delayed or even be fired.

(Psychologist)

The media attention to such crises added weight to the impact of self-harm. Cognizant of the powerful effect negative publicity had on the prison administration, prisoners sometimes alerted the media and human rights groups through illicit mobile phones or relatives about individual, or more often group, self-harm. The prison authorities always challenged such reports, labelling them as prisoner manipulation and, at times, accused human rights activists and the media of being mouthpieces or puppets of the criminal world (e.g. UkrPS, 25 October 2008, 8 July 2009). Establishing the truth in the absence 
of unbiased investigators poses an insurmountable challenge given the partiality of the UkrPS and many prisoner-rights activists, not to mention the sensationalist tendencies of the mass media in Ukraine. Yet the cumulative result was effective pressure on the UkrPS. The tangible desire of the administration to minimize external attention, even more so external intervention, emerged in many conversations and reactions (see Hepburn, 1984; Karklins, 1989; Sparks et al., 1996).

Many of my prisoner interlocutors concurred with the dominant view of self-harm as manipulation. However, some confided that in the past they had self-inflicted bleeding not for selfish gains but to halt police brutality (see CAT, 2017; CPT, 2017). The story of this prisoner librarian reflects the similar experience of several other prisoners with whom I spoke:

When I was in a district police department (rayotdél) they were beating me with fists and batons. When I felt that I couldn't stand it anymore I bit the skin open to bleed when the officers stepped out to have a cigarette.

While truly a desperate 'defence of the weak', self-harm proved effective - and prisoners assured me they would use it as a last resort if needed. However, their objective was not to seek attention or extra privileges but to defend their basic rights. I saw scars resulting from self-harm on the wrists and forearms of at least 10 prisoners. The UkrPS reported a staggering 431 cases of self-harm in 2016, of which nine were in the research prison (17 in 2017). Even if prisoners did self-harm as coercion or punishment-evasion, we should wonder how severe the punishment was that could provoke this extreme form of 'defence'. It highlights the personal cost for people inside this radically unequal power relationship. Although prisoners, individually and collectively, exploited the structural legacy of the Soviet scapegoating culture, this power contest resembled a war of attrition where managers and prisoners alike could be removed. However, for prisoners this removal usually meant a higher security category, additional custody, informal punishment by the administration or, in extreme cases, death.

\section{Conclusions}

The fact that, while being structurally subordinate, prisoners are not entirely powerless, constitutes a well-known paradox (inter alia, Crewe, 2009; Mathiesen, 1965; Sykes, 1958). Examining how prisoners, borrowing from Mathiesen, 'defended' themselves in this Ukrainian prison, I have demonstrated that, in line with accounts from elsewhere, the prisoners in my study daily contested officer power in multiple ways, often visibly and consequentially. Couched within these prisoner actions were various causes, intentions, meanings and outcomes. Owing to space constraints, I have omitted other modes of prisoner response to imprisonment in general and officer power in particular and focused only on those most consequential and mutually acknowledged as forms of resistance. ${ }^{8}$ The study demonstrates that dividing the prison population into the omnipotent powerful and the docile powerless is too simplistic (Bosworth, 1996; Kauffman, 1988; Mathiesen, 1965; Sykes, 1958).

The case of Ukraine, where the enduring Soviet legacies cohere with substantial democratization and liberalizing reforms, offers an instructive example of the mutual 
constitution of human agency and social structure (Gangas, 2016; Giddens, 1984; Rubin, 2017). Using official grievances as one example, I have demonstrated that rather than being an oppositional binary, structure and agency constantly interacted, working to transform each other. The Ukraine's 'de-Communization' and 'Europeanization' project reconstituted agents, augmenting a realization by some prisoners of their citizenship and rights-bearing subjectivity. This structurally amplified rights-consciousness enabled these prisoners, combining with another structural factor of officers' common legal illiteracy, to fend off officer power and reconstitute the internal structures of the prison's power dynamics. Even so, the entrenched, repressive penal culture (Piacentini and Katz, 2017) and its translation into prison ethos and practices (Garland, 1990), together with the legacy of ordinary citizens' 'internal colonization' (Shearer, 2015: 721) by the state and its colluding branches, diminished the capability (Gangas, 2016) and readiness of many prisoners to pursue a legally sanctioned form of resistance through official grievances. Conversely, by invoking the concept of negative visibility, I have advanced the case for the interplay of a local political culture with prisoner resistance. I have shown how the prisoners employed the resilient Soviet tradition of hierarchical blame assignment and displacement of responsibility to undermine, circumvent and fend off officer power. Thus, while the forms of prisoner resistance described resembled those in other jurisdictions, the underlying mechanisms and their pertinence reflected the local political ethos.

Prisoners actively engaged with structures, evaluating them, accepting and using some, while challenging others; thus they reinvented or reaffirmed themselves as autonomous, capable agents (Gangas, 2016; Giddens, 1984; Rubin, 2017; Ugelvik, 2014). ${ }^{9}$ Although power operated on many levels, in concrete and diffused forms alike, my practical focus on power relations between prisoners and officers revealed that concrete and immediate power on the ground entails equally tangible and front-stage resistance. Heeding Rubin's $(2015,2017)$ warning regarding the conflation of 'frictions' and resistance, I limited the discussion here to political examples of acknowledged and consequential prisoner resistance. I have demonstrated that prisoner power does not exclusively constitute a 'defence' against officer brutality and repressive regimes. Prisoners exploited structural factors, primarily the culture of scapegoating and the administration's profound avoidance of negative visibility and blame. They also had instrumental, selfish reasons, indicating that one should avoid the over-romanticization of the "defences of the weak' or a priori politicization of prisoners' resistance. As situated actors, prisoners and officers often calculated the cost-effectiveness of their (re)actions - and structural factors (e.g. understaffing interacting with the prison's topography) had a direct bearing on these (sometimes opportunistic) decisions, as I underscore in my discussion of force as a resistance tactic. ${ }^{10}$ This analysis has also illustrated that structure can simultaneously enable and constrain, comprising both means and outcomes of agents' interactions (see Gangas, 2016 on capability expansion and Giddens, 1984 on transformative capacity and duality of structure).

Countries' penal regimes in general, and individual prisons within them, differ enormously in their punitiveness, violence and how much leverage prisoners enjoy in power competition and inter-subjective relations (Calavita and Jenness, 2014; Crewe, 2009; Kauffman, 1988; King and McDermott, 1995; Liebling, 2004; McDermott and King, 1988; Pallot and Piacentini, 2012; Sparks et al., 1996). As a case study within an atypical, 
'showcase' prison, the findings presented and arguments proposed require some caution. Nonetheless, listening to the prisoners' accounts of their experiences in other prisons, and from sustained conversations during five months' living in the UkrPS Training Academy with officers from across Ukraine, the findings seem to replicate the situation in other Ukrainian medium-security prisons for sentenced men ('correctional colonies'). ${ }^{11}$ Furthermore, although I framed this discussion using the schematic opposition of prisoners and officers, I recognize that both groups have their own hierarchies and demonstrate important heterogeneity (Crewe, 2009; Goffman, 1961; Hollander and Einwohner, 2004; Mathiesen, 1965). I also acknowledge that a prisoner's decision not to contest officer power or prison regime is by no means a suggestion of their limited agency (Bosworth and Carrabine, 2001; Rubin, 2015).

Despite the study's limitations, using the case of Ukraine, a country that has undergone dramatic structural changes while retaining many Soviet remnants, has exposed the complex relationship and mutual constitution of structure and agency, and the interplay of a managerial culture and prisoner resistance. To summarize, power in prison is multidirectional and provisional, whilst actors' resources and capabilities are transient and contingent. They predicate on history (living memories), political and managerial tradition (common-sense practices, state branches' collusion and hierarchical displacement of blame), and legal framework ('Europeanization'-inspired normative expectations and external monitoring). Thus, notwithstanding the structural determinants of the inherent gross power imbalance, the interactional nature of power meant that neither of the groups was completely powerful, nor permanently powerless or 'defenceless'.

\section{Acknowledgements}

First and foremost, I thank my research participants for their humanity, patience, trust, and sense of humour. I wish you all the best. Dr Margaret Wilson is well aware of my indebtedness; nonetheless, thank you once again for your inestimable help. I thank Tamara Symkovych for her assistance with collating data from the UkrPS web site and other open sources. My gratitude also goes to Andriy Vygovsky, Alla Grygorenko, Vitaliy Kryukov, as well as Gerda Henkel Foundation.

I presented the earlier drafts of this article at the Global Prison Conference, University of Johannesburg (South Africa) and the annual conference of the Australian Sociological Association, Perth (Australia) in November 2017.

\section{Funding}

The author(s) received no financial support for the research, authorship, and/or publication of this article.

\section{Notes}

1. Frictions can be interpreted as, or develop into, resistance, but academics tend a priori or ex post facto to conflate them (Carrabine, 2005; Rubin, 2015, 2017). For examples of this borderline friction-adaptation-resistance see Crewe (2009), Pallot and Piacentini (2012), Reed (2003), Thomas (1984), Ugelvik (2014).

2. From a total 1,188 ECtHR judgments against Ukraine since its accession to the Council of Europe in 1995, the greatest number concerns the state's violation of the right to a fair trial (529) and length of proceedings (353), as well as inhuman or degrading treatment (170) and 
right to effective remedy (247), illustrating the entrenched failures of the Ukrainian justice and law-enforcement systems (ECtHR, 2018b).

3. See Calavita and Jenness (2014) and Piacentini (2004) on the benefits of outsider status in prison research.

4. Naturally, there are many other forms, not least manipulation, persuasion, inducement or censoriousness (e.g. Kauffman, 1988; Mathiesen, 1965; Thomas, 1984).

5. Following each reorganization, the UkrPS website lost part of its archive. Since the UkrPS's complete merger into the Ministry of Justice in 2016, the Ministry stopped publishing prisonrelated information, even hitherto customary statistics. I draw on the press releases that formerly appeared on the UkrPS website and list those still retrievable in the References.

6. I define coercion as physically non-violent whereby another person's behaviour is manipulated by means that bring negative consequences other than physical force. This includes the actual recourse to such means and expressed or perceived threats to use them (Bachman et al., 1966).

7. One exception was, in official parlance, a 'loss of socially significant connections on the outside' as a reason for suicide. However, in some cases staff recognized alternative reasons, notably, shame and refusal to accept a downgrade in prisoner hierarchy following the inability to honour a gambling debt (Symkovych, 2017b). The UkrPS reported eight suicides in 2017, including two in the research prison.

8. Here I refer to Hollander and Einwohner's (2004) taxonomy. Furthermore, I have described only those tactics used as resistance tools not merely as a means to derive benefit or pleasure per se (Rubin, 2015).

9. Elsewhere I demonstrate that while populating a different end of the nexus of penal power from the prisoners', power-holders also evaluate and resist the penal structures, not merely embrace or use them uncritically (Symkovych, 2018). Similarly, Khlevniuk (2004) cites stark examples of street-level bureaucrats resisting repressive penal policies to reduce the Stalinist effect on ordinary citizens. See also Karklins (1989).

10. This does not imply that people always constitute prudential agents, nor that actions inevitably bring about their intended consequences.

11. All my respondents concurred that the power dynamics in remand prisons (SIZO) differ enormously from those in training prisons. Likewise, the maximum-security sectors housing lifesentenced prisoners who do not associate with prisoners from other cells must produce a different type of order and power relations; as must prisons where the managing team instils a climate of fear and intimidation (CPT, 2015a, 2017).

\section{ORCID iD}

Anton Symkovych iD https://orcid.org/0000-0001-8477-5783

\section{References}

Akoensi T (2014) Governance through power sharing in Ghanaian prisons: A symbiotic relationship between officers and inmates. Prison Service Journal 212: 33-39.

Bachman JG, Bowers D and Marcus P (1968) Bases of supervisory power: A comparative study in five organizational settings. In: Tannenbaum AS (ed.) Control in Organizations. London: McGraw-Hill Book Company, pp. 229-238.

Bachman JG, Smith CG and Slesinger JA (1966) Control, performance, and satisfaction: An analysis of structural and individual effects. Journal of Personality and Social Psychology 4(2): 127-136.

Berg BL (2001) Qualitative Research Methods for Social Sciences. Needham Hights, MA: Allyn and Bacon. 
Berger L (2001) Inside out: Narrative autoethnography as a path toward rapport. Qualitative Inquiry 7(4): 504-518.

Bosworth M (1996) Resistance and compliance in women's prisons: Towards a critique of legitimacy. Critical Criminology 7(2): 5-19.

Bosworth M and Carrabine E (2001) Reassessing resistance: Race, gender and sexuality in prison. Punishment and Society 3(4): 501-515.

Bosworth M and Slade G (2014) In search of recognition: Gender and staff-detainee relations in a British immigration removal centre. Punishment and Society 16(2): 169-186.

Bottoms AE (1999) Interpersonal violence and social order in prisons. In: Tonry M and Petersilia J (eds) Crime and Justice: Review of Research, Vol. 26. Chicago, IL: University of Chicago Press, 205-282.

Bottoms AE (2007) The relationship between theory and empirical observations in criminology. In: King RD and Wincup E (eds) Doing Research on Crime and Justice. Oxford: Oxford University Press, 75-116.

Calavita K and Jenness V (2014) Appealing to Justice: Prisoner Grievances, Rights, and Carceral Logic. Oakland, CA: University of California Press.

Carrabine E (2005) Prison riots, social order and the problem of legitimacy. British Journal of Criminology 45(6): 896-913.

CAT (Committee Against Torture) (2017) Visit to Ukraine undertaken from 19 to 25 May and from 5 to 9 September 2016: Observations and recommendations addressed to the State party. CAT/OP/UKR/3. Available at: http://tbinternet.ohchr.org/_layouts/treatybodyexternal/ Download.aspx? symbolno $=\mathrm{CAT} / \mathrm{OP} / \mathrm{UKR} / 3$

Christie N (1978) Prisons in society, or society as a prison-a conceptual analysis. In: Freeman JC (ed.) Prisons Past and Future: In Commemoration of the Bi-Centenary of John Howard's 'The State of the Prisons'. London: Heinemann Educational Books, 179-187.

Cloward RA (1960) Social control in the prison. In: Cloward RA, Cressey DR, Grosser GH, et al. (eds) Theoretical Studies in Social Organization of the Prison. New York: Social Science Research Council, 20-48.

Cohen S and Taylor L (1972) Psychological Survival: The Experience of Long-Term Imprisonment. Harmondsworth: Penguin.

Constitution of Ukraine (1996) Available at: http://zakon2.rada.gov.ua/laws/show/254k/96-Bp (accessed 8 May 2018).

CPT (European Committee for the Prevention of Torture and Inhuman or Degrading Treatment or Punishment) (2015a) Report to the Ukrainian Government on the visit to Ukraine carried out by the European Committee for the Prevention of Torture and Inhuman or Degrading Treatment or Punishment (CPT) from 9 to 16 September 2014. CPT/Inf (2015) 21. Available at: http://www.cpt.coe.int/documents/ukr/2015-21-inf-eng.pdf (accessed 8 May 2018).

CPT (European Committee for the Prevention of Torture and Inhuman or Degrading Treatment or Punishment) (2015b) Response of the Ukrainian Government to the report of the European Committee for the Prevention of Torture and Inhuman or Degrading Treatment or Punishment (CPT) on its visit to Ukraine from 9 to 16 September 2014. CPT/Inf (2015) 24. Available at: http://www.cpt.coe.int/documents/ukr/2015-24-inf-eng.pdf (accessed 8 May 2018).

CPT (European Committee for the Prevention of Torture and Inhuman or Degrading Treatment or Punishment) (2017) Report to the Ukrainian Government on the visit to Ukraine carried out by the European Committee for the Prevention of Torture and Inhuman or Degrading Treatment or Punishment (CPT) from 21 to 30 November 2016. CPT/Inf (2017) 15. Available at: https://rm.coe.int/pdf/1680727930 (accessed 8 May 2018).

Crewe B (2009) The Prisoner Society. Oxford: Oxford University Press. 
Criminal-Executive Code of Ukraine (2003) Available at: http://zakon2.rada.gov.ua/laws/ show/1129-15/print1308485384754605 (accessed 8 May 2018).

Dear GE, Thomson DM and Hills AM (2000) Self-harm in prison: Manipulators can also be suicide attempters. Criminal Justice and Behavior 27(2): 160-175.

ECtHR (European Court of Human Rights) (2018a) Analysis of statistics 2017. Available at: http://www.echr.coe.int/Documents/Stats_analysis_2017_ENG.pdf (accessed 8 May 2018).

ECtHR (European Court of Human Rights) (2018b) Overview 1959-2017. Available at: https:// www.echr.coe.int/Documents/Overview_19592017_ENG.pdf (accessed 8 May 2018).

Erpylyeva S (2018) Freedom's children in protest movements: Private and public in the socialization of young Russian and Ukrainian activists. Current Sociology 66(1): 20-37.

Foucault M (1975/1991) Discipline and Punish: The Birth of the Prison. London: Penguin Books.

Foucault M (1978) The History of Sexuality, Vol. 1: An Introduction. Trans Hurley R. New York: Pantheon.

Gangas S (2016) From agency to capabilities: Sen and sociological theory. Current Sociology 64(1): 22-40.

Garabedian PG (1963) Social roles and processes of socialization in the prison community. Social Problems 11(2): 139-152.

Garland D (1990) Punishment and Modern Society. Oxford: Clarendon Press.

Ghorashi H, De Boer M and Ten Holder F (2018) Unexpected agency on the threshold: Asylum seekers narrating from asylum seeker centre. Current Sociology 66(3): 373-391.

Giddens A (1984) The Constitution of Society. Cambridge: Cambridge University Press.

Goffman E (1961) On the characteristics of total institutions: Staff-inmate relations. In: Cressey DR (ed.) The Prison: Studies in Institutional Organization and Change. New York: Holt, Rinehart and Winston, 68-106.

Hepburn JR (1984) The erosion of authority and the perceived legitimacy of inmate social protest: A study of prison guards. Journal of Criminal Justice 12(6): 579-590.

Hepburn JR (1985) The exercise of power in coercive organizations: A study of prison guards. Criminology 23(1): 146-164.

Hollander JA and Einwohner RL (2004) Conceptualizing resistance. Sociological Forum 19(4): 533-554.

Karklins R (1989) The organisation of power in Soviet labour camps. Soviet Studies 41(2): 276-297.

Karstedt S (2013) Trusting authorities: Legitimacy, trust, and collaboration in non-democratic regimes. In: Tankebe J and Liebling A (eds) Legitimacy and Criminal Justice: An International Exploration. Oxford: Oxford University Press, 127-156.

Kauffman K (1988) Prison Officers and Their World. Cambridge, MA: Harvard University Press.

Khlevniuk O (2004) The History of the Gulag: From Collectivization to the Great Terror. Trans. Staklo V. New Haven, CT: Yale University Press.

Khlevniuk O (2015) The Gulag and the non-Gulag as one interrelated whole. Kritika: Explorations in Russian and Eurasian History 16(3): 479-498.

King RD and Elliott KW (1977) Albany: Birth of a Prison-End of an Era. London: Routledge \& Kegan Paul.

King RD and McDermott K (1995) The State of Our Prisons. Oxford: Clarendon Press.

Liebling A (1992) Suicides in Prison. London: Routledge.

Liebling A (2004) Prisons and Their Moral Performance: A Study of Values, Quality, and Prison Life. Oxford: Oxford University Press.

McDermott K and King RD (1988) Mind games: Where the action is in prisons. British Journal of Criminology 28(3): 357-377.

Martin TM (2014) The importation of human rights by Ugandan prison staff. Prison Service Journal 212: 45-51. 
Mathiesen T (1965) The Defences of the Weak: A Sociological Study of a Norwegian Correctional Institution. London: Tavistock Publications.

Oleinik AN (2003) Organized Crime, Prison and Post-Soviet Societies. Aldershot: Ashgate Publishing.

Othmani A (2008) Beyond Prison: The Fight to Reform Prison Systems Around the World. Oxford: Berghahn Books.

Pallot J (2015) The Gulag as the crucible of Russia's 21st-century system of punishment. Kritika: Explorations in Russian and Eurasian History 16(3): 681-710.

Pallot J and Piacentini L (2012) Gender, Geography, and Punishment: The Experience of Women in Carceral Russia. Oxford: Oxford University Press.

Piacentini L (2004) Surviving Russian Prisons: Punishment, Economy and Politics in Transition. Cullompton: Willan Publishing.

Piacentini L and Katz E (2017) Carceral framing of human rights in Russian prisons. Punishment and Society 19(2): 221-239.

Piacentini L and Slade G (2015) Architecture and attachment: Carceral collectivism and the problem of prison reform in Russia and Georgia. Theoretical Criminology 19(2): 179-197.

Prison Bye-laws (2014) Available at: http://zakon3.rada.gov.ua/laws/show/z1656-14 (accessed 8 May 2018).

Radio Freedom (2017) Why the penitentiary system is sick: The Odesa SIZO tragedy as a mirror. Available at: https://www.radiosvoboda.org/a/28688876.html (accessed 8 May 2018).

Reed A (2003) Papua New Guinea's Last Place: Experiences of Constraint in a Postcolonial Prison. Oxford: Berghahn Books.

Rubin AT (2015) Resistance or friction: Understanding the significance of prisoners' secondary adjustments. Theoretical Criminology 19(1): 23-42.

Rubin AT (2017) Resistance as agency? Incorporating the structural determinants of prisoner behaviour. British Journal of Criminology 57(3): 644-663.

Scott J (2001) Power. Cambridge: Polity Press.

Scraton P, Sim J and Skidmore P (1991) Prisons under Protest. Buckingham: Open University Press.

Shearer DR (2015) The Soviet Gulag — an archipelago? Kritika: Explorations in Russian and Eurasian History 16(3): 711-724.

Smith P (2008) Punishment and Culture. Chicago, IL: University of Chicago Press.

Sparks R, Bottoms AE and Hay W (1996) Prisons and the Problem of Order. Oxford: Clarendon Press.

Sykes GM (1958) The Society of Captives: A Study of a Maximum Security Prison. Princeton, NJ: Princeton University Press.

Symkovych A (2017a) Do men in prison have nothing to lose but their manhood? Masculinities of prisoners and officers in a Ukrainian correctional colony. Men and Masculinities. Epub ahead of print 1 March 2017. DOI: https://doi.org/10.1177/1097184X17696172.

Symkovych A (2017b) The 'inmate code' in flux: A normative system and extralegal governance in a Ukrainian prison. Current Sociology. Epub ahead of print 20 December 2017. DOI: https://doi.org/10.1177/0011392117744596.

Symkovych A (2017c) The Ukrainian response to Sykes: Prisoner hierarchy and self-rule - power, legitimacy, and dynamics. British Journal of Criminology. Epub ahead of print 20 December 2017. DOI: https://doi.org/10.1093/bjc/azx076.

Symkovych A (2018) Compromised power and negotiated order in a Ukrainian prison. British Journal of Criminology 58(1): 200-217.

Tamanaha BZ (2004) On the Rule of Law: History, Politics, Theory. Cambridge: Cambridge University Press. 
Thomas J (1984) Some aspects of negotiated order, loose coupling and mesostructure in maximum security prisons. Symbolic Interaction 7(2): 213-231.

Ugelvik T (2014) Power and Resistance in Prison: Doing Time, Doing Freedom. London: Palgrave.

UkrPS (2010) Information about the so-called 'events' in Kuryazh educational colony, 14 May 2010. Available at: http://ukrprison.org.ua/news/1274067983 (accessed 8 May 2018).

UkrPS (2016) Prisoner assaulting an officer in Sokyryanska correctional colony (No 67) in the Chernivtsi region, 10 June 2016. Available at: http://www.kvs.gov.ua/peniten/control/main/ uk/publish/article/836731 (accessed 8 May 2018).

UkrPS (2016) The situation in the Odesa correctional colony (No 14) has been stabilised, 15 August 2016. Available at: http://www.kvs.gov.ua/peniten/control/main/uk/publish/article/846030 (accessed 8 May 2018).

Useem B and Piehl AM (2006) Prison buildup and disorder. Punishment and Society 8(1): 87-115. Weber M (1962) Basic Concepts in Sociology. London: Peter Owen.

Wrong DH (2004) Power: Its Forms, Bases, and Uses. London: Transaction Publishers.

\section{Author biography}

Anton Symkovych is a postdoctoral research fellow in the Sociology Department at the University of Johannesburg, South Africa and Gerda Henkel fellow at the Centre for Advanced Study-Sofia, Bulgaria. His research interests include, inter alia, prisoner power structures and the role of power and legitimacy in generation of prison order. 